\title{
Abbreviations and Bibliography
}

The following abbreviations are used in the references to entries in A Basic Bahá'í Chronology. In general, figures following an abbreviation denote the page number or numbers, e.g. AB7, 9 refers to Balyuzi's 'Abdu'l-Bahá, pages 7 and 9. Where a title is in multiple volumes, such as Bahá’ World, a colon separates the title and volume number from the page numbers. Thus BW18:16 refers to Bahá’ World, volume 18, page 16 (see individual books below for further examples). Occasionally a colon is used in a reference for clarity, e.g. 239D:65 refers to Allan Ward's 239 Days, page 65.

239D Ward, Allan L. 239 Days. Wilmette, Ill.: Bahá’í Publishing Trust, 1979.

AB Balyuzi, H. M. 'Abdu'l-Bahá. Oxford: George Ronald, 1971.

ABMM Momen, Moojan. 'Abdu'l-Bahá. Manuscript.

ADJ Shoghi Effendi. The Advent of Divine Justice. Wilmette, Ill.: Bahá'í Publishing Trust, 1990.

AVI Nakhjavání, Violette. Amatu’l-Bahá Visits India. New Delhi: Bahá'í Publishing Trust, 1984.

AWH The Universal House of Justice. A Wider Horizon: Selected Messages of the Universal House of Justice 1983-1992. Riviera Beach, FL: Palabra Publications, 1992.

B Balyuzi, H. M. The Báb. Oxford: George Ronald, 1973.

BA Shoghi Effendi. Bahá’’ Administration. Wilmette, Ill.: Bahá’í Publishing Trust, 1968.

BBD Momen, Wendi. A Basic Bahá’’́ Dictionary. Oxford: George Ronald, 1989.

BBIC Baháu'lláh. A statement prepared by the Bahá'i International Community Office of Public Information. London: Bahá’í Publishing Trust, 1991.

BBR Momen, Moojan. The Bábí and the Bahá’i Religions, 1844-1944, Some Contemporary Western Accounts. Oxford: George Ronald, 1981.

BBRSM Smith, Peter. The Bábí and Bahá’̌ Religions. Cambridge: Cambridge University Press, 1987.

BEL Collins, William. Bibliography of English-Language Works on the Bábí and Bahá’i Faiths, 1844-1985. Oxford: George Ronald, 1990.

BFA1 Stockman, Robert. The Baháł Faith In America, vol. 1. Wilmette, Ill.: Bahá’í Publishing Trust, 1985 .

BFA2 Stockman, Robert. The Bahá' Faith in America, Early Expansion, 19oo-1912, vol. 2. Oxford: George Ronald, 1995.

BHC Bahá’́ History Calendar. Honolulu, Hawaii: Hawaii Bahá’í National Library.

BHP The Universal House of Justice. Bahá’’ Holy Places at the World Centre. Haifa: Bahá’í World Centre, 1968.

BI Cooper, Roger. The Bahá’ís of Iran. No. 51, Minority Rights Group series. Feb. 1982. 
BINS Baháı́ International News Service. Issued fortnightly by the Bahá'í World Centre. [Issues are indicated by edition number followed by page number; thus BINS210:8 refers to Baháı International News Service, number 210, page 8.]

BK Bahá’yyyih Khánum. Haifa: Bahá'í World Centre, 1982.

BKG Balyuzi, H. M. Baháu’lláh, The King of Glory. Oxford: George Ronald, 1980.

BN Bahá’ News. A monthly publication of the National Spiritual Assembly of the United States. [Figures following 'BN' refer to volume number and page number, thus BN596:14 refers to Baháı News, volume 596, page 14.

BNE Esslemont, J. E. Bahá'u’lláh and the New Era. London: Bahá'í Publishing Trust, 1974.

BR Smith, Peter. The Bahá’ Religion: A Short Introduction to its History and Teachings. Oxford: George Ronald, 1988.

BW Bahá' World. Prepared under the supervision of the National Spiritual Assembly of the United States and Canada with the approval of Shoghi Effendi or prepared by the Universal House of Justice. [Figures appearing after 'BW' refer to volume numbers, thus BW8:25 refers to Bahá’ World, volume 8, page 25. From 1992-3, Bahá’ World is dated year by year rather than by volume number. Thus BW92-3:6 refers to Bahá’ World, 1992-3, page 6.]

BWMF Balyuzi, H. M. Baháu’lláh, The Word Made Flesh. Oxford: George Ronald, 1963.

CB Taherzadeh, Adib. The Covenant of Baháu'lláh. Oxford: George Ronald, 1992.

CBM Matthews, Gary L. The Challenge of Baháu'lláh. Oxford: George Ronald, 1993.

CF $\quad$ Shoghi Effendi. Citadel of Faith. Wilmette, Ill.: Bahá'i Publishing Trust, 1980.

CH Blomfield, Lady. The Chosen Highway. Wilmette, Ill.: Bahá'í Publishing Trust, 1975.

CT $\quad$ Rutstein, Nathan. Corinne True. Oxford: George Ronald, 1987.

GTT Shoghi Effendi. Guidance for Today and Tomorrow. London: Bahá'í Publishing Trust, 1953

DB Nabíl-i-A‘zam. The Dawn-Breakers, Wilmette, Ill.: Bahá’í Publishing Trust, 1970.

DG Shoghi Effendi. Directives from the Guardian. New Delhi: Bahá'í Publishing Trust, 1973.

DH Ruhe, David S. Door of Hope. Oxford: George Ronald, 1983.

DJEE Momen, Moojan. Dr. J. F. Esslemont. London: Bahá'í Publishing Trust, 1975.

DJT The Diary of Juliet Thompson. Los Angeles: Kalimát Press, 1983.

DM Muhájir, Írán Furútan. Dr Muhájir Hand of the Cause of God, Knight of Baháu'lláh. London: Bahá'í Publishing Trust, 1992.

DND Shoghi Effendi. Dawn of a New Day. New Delhi: Bahá’í Publishing Trust, 1970.

DP Whitmore, Bruce W. The Dawning Place. Wilmette, Ill.: Bahá’í Publishing Trust, 1984.

EB Balyuzi, H. M. Eminent Bahá’ís in the Time of Baháu'lláh. Oxford: George Ronald, 1985.

EGB Balyuzi, H. M. Edward Granville Browne and the Bahá’’ Faith. London: George Ronald, 1970. 
ER Weinberg, Robert. Ethel Jenner Rosenberg, Oxford: George Ronald, 1995.

ESW Bahá'u'lláh. Epistle to the Son of the Wolf. Wilmette, Ill.: Bahá'í Publishing Trust, 1971.

FGM Vader, John Paul. For the Good of Mankind: August Forel and the Bahái Faith. Oxford: George Ronald, 1984.

G Bahá'u'lláh. Gleanings from the Writings of Baháu'lláh. Wilmette, Ill.: Bahá’í Publishing Trust, 1983 .

GAP Green Acre on the Piscataqua. Eliot, Maine: Green Acre Bahá’í School Council, 1991.

GBF Rabbání, Rúhíyyih. The Guardian of the Bahá’ Faith. London: Bahá’í Publishing Trust, 1988.

GPB Shoghi Effendi. God Passes By. Wilmette, Ill.: Bahá'í Publishing Trust, 1970.

GT Hofman, David. George Townshend. Oxford: George Ronald, 1983.

HLS Rutstein, Nathan. He Loved and Served. Oxford: George Ronald, 1982.

I Khianra, Dipchand. Immortals. New Delhi: Bahá’’ Publishing Trust, 1988.

KA Bahá'u’lláh. The Kitáb-i-Aqdas. Haifa: The Bahá’í World Centre, 1992.

KAN Notes to The Kitáb-i-Aqdas.

KB Balyuzi, H. M. Khadíjih Bagum. Oxford: George Ronald, 1981.

KI Bahá'u'lláh. The Kitáb-i-Íqán. Wilmette, Ill.: Bahá’í Publishing Trust, 1989.

L Heller, Wendy. Lidia. Oxford: George Ronald, 1985.

LANZ Shoghi Effendi. Letters from the Guardian to Australia and New Zealand. Sydney, Australia: Bahá'í Publishing Trust, 1970.

LDG1\&2 Shoghi Effendi. The Light of Divine Guidance: The Messages from the Guardian of the Bahá'i Faith to the Bahá'ís of Germany and Austria. Hotheim-Langenhaim: Bahá'i-Verlag, 1982.

LOG Hornby, Helen, comp. Lights of Guidance. New Delhi: Bahá'í Publishing Trust, 1983.

MA Shoghi Effendi. Messages to America. Wilmette, Ill.: Bahá’í Publishing Trust, 1947.

MAP Phelps, Myron H. The Master in 'Akká. Los Angeles: Kalimát Press, 1985.

MBW Shoghi Effendi. Messages to the Bahá’’ World. Wilmette, Ill.: Bahá'i Publishing Trust, 1971.

MC The Ministry of the Custodians, 1957-1963: An Account of the Stewardship of the Hands of the Cause. Haifa: Bahá'í World Centre, 1992.

MF 'Abdu'l-Bahá. Memorials of the Faithful. Wilmette, Ill.: Bahá’í Publishing Trust, 1971.

MH Mehrabhani, R. Mullá Husayn, Disciple at Dawn. Los Angeles: Kalimát Press, 1987.

MKBM Ma’ani, Baharieh. Munírih Khánum. Manuscript.

MMBA Momen, Moojan. Mullá 'Alí Bastámí. Manuscript.

MMNF Momen, Moojan. The Núrí Family. Manuscript. 
MR Garis, M. R. Martha Root: Lioness at the Threshold. Wilmette, Ill.: Bahá'í Publishing Trust, 1983.

MRHK Zinky, Kay, comp. Martha Root, Herald of the Kingdom. New Delhi: Bahá’í Publishing Trust, 1983.

MS Salmanpour, Manuchehr. Arabia. Manuscript.

MUHJ The Universal House of Justice. Messages from the Universal House of Justice 1968-1973. Wilmette, Ill.: Bahá'í Publishing Trust, 1976.

OC One Country. A publication of the Bahá'i International Community Office of Public Information.

PDC Shoghi Effendi. The Promised Day is Come. Wilmette, Ill.: Bahá'í Publishing Trust, 1951.

PH Seow, Jimmy Ewe Huat. The Pure in Heart: The Historical Development of the Bahá'z Faith in China, Southeast Asia and Far East. Sydney: Bahá'í Publications Australia, 1991.

PP Rabbání, Rúhíyyih. The Priceless Pearl. London: Bahá'í Publishing Trust, 1969.

PSBW Whitehead, O. Z. Portraits of Some Bahá’ Women. Oxford: George Ronald, 1996.

PT Abdu'l-Bahá. Paris Talks. London: Bahá'í Publishing Trust, 1995.

PUP 'Abdu'l-Bahá. The Promulgation of Universal Peace. Wilmette, Ill.: Bahá'í Publishing Trust, 1982.

RB1 Taherzadeh, Adib. The Revelation of Baháu'lláh, vol. 1. Oxford: George Ronald, 1974.

RB2 Taherzadeh, Adib. The Revelation of Baháu'lláh, vol. 2. Oxford: George Ronald, 1977.

RB3 Taherzadeh, Adib. The Revelation of Baháu’lláh, vol. 3. Oxford: George Ronald, 1983.

RB4 Taherzadeh, Adib. The Revelation of Baháu'lláh, vol. 4. Oxford: George Ronald, 1987.

RG Braun, Eunice. A Reader's Guide: The Development of Bahá’̌ Literature in English. Oxford: George Ronald, 1986.

RR Amanat, Abbás. Resurrection and Renewal. London: Cornell University Press, 1989.

RSLG Garrigues, Stephen L. Rúmí. Manuscript.

SA Walbridge, John. Sacred Acts, Sacred Space, Sacred Time. Oxford: George Ronald, 1996.

SB Furútan, 'Alí-Akbar. Stories of Baháu’lláh. Oxford: George Ronald, 1986.

SBBH1 Momen, Moojan, ed. Studies in Bábí and Baháž History, vol. 1. Los Angeles: Kalimát Press, 1982.

SBBH2 Cole, Juan R. and Momen, Moojan, eds. Studies in Bábí and Baház History: From Iran East \& West. Los Angeles: Kalimát Press, 1984.

SBBR5 Momen, Moojan, ed. Studies in the Bábí and Bahá’ Religions: Studies in Honor of the Late Hasan M. Balyuzi. Los Angeles: Kalimát Press, 1988.

SBR Whitehead, O. Z. Some Bahá’’s to Remember. Oxford: George Ronald, 1983.

SDC 'Abdu’l-Bahá. The Secret of Divine Civilization. Wilmette, Ill.: Bahá’í Publishing Trust, 1990. 
SDH Faizí, A. Q. The Delight of Hearts: Memoirs of Hájí Mírzá Haydar-'Alí. Los Angeles: Kalimát Press, 1980.

SE Giachery, Ugo. Shoghi Effendi. Oxford: George Ronald, 1973.

SEBW Whitehead, O. Z. Some Early Bahá's of the West. Oxford: George Ronald, 1976.

SI Momen, Moojan. An Introduction to Shi`i Islam. London: Yale University Press, 1985.

SS $\quad$ Braun, Eunice. From Strength to Strength. Wilmette, Ill.: Bahá’í Publishing Trust, 1978.

SUR Gail, Marzieh. Summon Up Remembrance. Oxford: George Ronald, 1987.

SW Star of the West, vols. 1-14. rpt. Oxford: George Ronald, 1978. [Figures appearing after 'SW' refer to volume and number; thus SW6,13:101 refers to Star of the West, volume 6, number 13, page 101. Some are identified merely by a volume number, thus sw13:277 refers to Star of the West, volume 13, page 277.]

SWAB 'Abdu'l-Bahá. Selections from the Writings of 'Abdu'l-Bahá. Haifa: Bahá'í World Centre, 1978.

SWB Báb, The. Selections from the Writings of the Báb. Haifa: Bahá’í World Centre, 1976.

TB Bahá'u'lláh. Tablets of Baháu'lláh revealed after the Kitáb-i-Aqdas. Haifa: Bahá'i World Centre, 1978.

TDP 'Abdu'l-Bahá. Tablets of the Divine Plan. Wilmette, Ill.: Bahá'í Publishing Trust, 1980.

TMW Morrison, Gayle. To Move the World. Wilmette, Ill.: Bahá'í Publishing Trust, 1982.

TN Abdu'l-Bahá. A Traveller's Narrative. Wilmette, Ill.: Bahá’í Publishing Trust, 1980.

TR Sims, Barbara R. Traces that Remain. Japan: Bahá'í Publishing Trust, 1989.

UD Shoghi Effendi. Unfolding Destiny of the British Bahá’ Community. London: Bahá'í Publishing Trust, 1981.

V Honnold, Annamaire. Vignettes from the Life of 'Abdu'l-Bahá. Oxford: George Ronald, rev. ed. 1991.

VV Braun, Eunice. From Vision to Victory. Oxford: George Ronald, 1993.

WG The Universal House of Justice. Wellspring of Guidance. Wilmette, Ill.: Bahá'i Publishing Trust, 1976.

WOB Shoghi Effendi. The World Order of Baháu'lláh. Wilmette, Ill.: Bahá'í Publishing Trust, 1991.

WT 'Abdu'l-Bahá. The Will and Testament of 'Abdu'l-Bahá. Wilmette, Ill.: Bahá'í Publishing Trust, 1971.

ZK Khadem, Javidukht. Zikrullah Khadem, The Itinerant Hand of the Cause of God. Wilmette, Ill.: Bahá’́ Publishing Trust, 1990. 


\section{Other Sources Cited}

'Abdu’l-Bahá in Canada. Ontario: Bahá'í Distribution Canada, 1962.

Faizí, A. O. Milly: A Tribute to Amelia E. Collins. Oxford: George Ronald, 1977.

Freeman, Dorothy. From Copper to Gold: The Life of Dorothy Baker. Oxford: George Ronald, 1984.

Gail, Marzieh. Khánum: The Greatest Holy Leaf. Oxford: George Ronald, 1982.

Hatcher, John S. From the Auroral Darkness: The Life and Poetry of Robert Hayden. Oxford: George Ronald, 1984.

Hein, Kurt John. Radio Bahá’ Ecuador. Oxford: George Ronald, 1988.

Khursheed, Anjam. The Seven Candles of Unity. London: Bahá'i Publishing Trust, 1991

Labíb, Muhammad. The Seven Martyrs of Hurmuzak. Oxford: George Ronald, 1981.

Momen, Moojan. Selections from the Writings of E. G. Browne. Oxford: George Ronald, 1987.

Sears, William and Quigley, Robert. The Flame: The Story of Lua. Oxford: George Ronald, 1972.

Szanto-Felbermann, Renée. Rebirth: The Memoirs of Renée Szanto-Felbermann. London: Bahá’í Publishing Trust, 1980.

Vick, Holly Hanson. Social and Economic Development: A Bahá’ Approach. Oxford: George Ronald, 1989.

West, Marion. Letters from Bonaire. Oxford: George Ronald, 1990. 